\title{
Existing Condition of Shorea robusta Forest and its Management: A Case Study from Nabadurga Community Forest, Dang District, Nepal
}

\author{
Saurav Lamichhane* and Arun Sharma Poudyal \\ Kathmandu Forestry College, Nepal
}

Submission: September 09, 2019; Published: November 19, 2019

*Corresponding author: Saurav Lamichhane, Kathmandu Forestry College, Kathmandu, Nepal

\begin{abstract}
Shorea robusta (Sal) forest management is highly challenging issue in Terai and inner Terai region of Nepal. There are very few studies related to Sal forest management. The study was carried out in Nabadurga Community forest, Dang district, Nepal in 2018 to analyze existing condition of Sal forest and its management practices. Furthermore, the research intends to offer suggestions for managing Sal forest in productive manner. A plot Size of $25^{*} 20$ was employed for trees, $10 \mathrm{~m} * 10 \mathrm{~m}$ for poles, $5 \mathrm{~m} * 5 \mathrm{~m}$ for sapling and $5 \mathrm{~m} * 2 \mathrm{~m}$ for seedling. PRA tools such as household survey, focus group discussion and key informants survey were carried out for social data collection. Likert Scale method was used for analyzing perception of respondents. Data collected during the field was analyzed using both quantitative and qualitative methods. The result obtained from the study shows that there is a need of improvement in the existing forest management system. Recent management technique doesn't seem enough to fulfill the demand of users adequately along with not being very profitable economically. Moreover, people's perception towards the forest is protection oriented. The CF is pure Sal forest comprising 94\% of total species in all classes (seedling, sapling, poles and trees). It shows that the regeneration status and growing stock of the CF is good which signifies that the condition of forest is also good. However, for the fulfillment of user's demand, social satisfaction and economic viability, the forest management system should be directed towards Scientific Forest Management.
\end{abstract}

Keywords: Community forest; PRA tools; Regeneration; Growing stock

\section{Information}

Community forestry (CF) program is regarded as one of the most successful program in Nepal [1]. The forest resources near to the settlements are handed over to local community for protection, management and utilization. The participation of local people in forest resources management has been initiated from 1978 in Nepal. There is considerable evidence that community forest is improving forest protection and regeneration [2]. However, at the same time many believe that community forest management is protection oriented where the main forest management activities are limited to removal of dead, dying trees and leaf litter. As a consequence, the users are getting suboptimal benefits [3,4]. Management of Terai forests has remained unsolved problem throughout its history. Past attempts (in 1970s) of forest management could not be fully implemented $[5,6]$. Later in the 1990 s, it was realized that the existing forest management practices were unsustainable [7]. There is a growing demand for information from local community as well as forestry professional on how forest could be managed to meet the demand of forest products essential to sustain rural livelihood [8].
Sal is the most important tree species in Terai region of Nepal. Sal Forests in Nepal cover one million ha, representing more than $16 \%$ of the total forest of the country [9]. For this species, natural regeneration is the only relevant method of regeneration [10] and silvicultural operations are required to improve the productivity [11]. As found by the study of DFRS [11] about Scientific Forest Management (SFM) areas of Kapilvastu district, Sal forests are managed under simple coppice, coppice with standards and coppice with reserves besides all high forest systems (selection, clear felling and shelter wood). However, irregular shelterwood system, with eight years of cutting cycle, has been recommended as 'the best expedient' by researchers for Sal forests [12] including the degraded non degraded forests to get better outcomes for new generations. Sal forests are distributed on the plains and lower foothills of the Himalayas including the valleys [13]. The ranges of areas vary considerably. It is highest at Dang district in about 130,000 hectares and lowest in Jhapa district in about 200 hectares [14]. In present days the forests are protected, and green felling is prohibited. However, due to lack of planned management, despite being put under total protection, forests are degrading in quantity and quality [15]. In 
Nabadurga CF intensive forest management opportunities exist with the application of proper silvicultural System in 207 ha of area to enhance the production and productivity of the pure Sal forest. Thus, this research was an attempt to explore existing condition of Sal forest and its management and offers suggestion for the changes in existing management practices.

\section{Materials and Methods}

\section{Study area}

The study was conducted in Nabadurga community forest of Dang district. The district falls under province No 5, Nepal. The site selection was done in consultation with forestry personnel from district forest office, Dang. After careful study on the potential sites, Nabadurga community forest was selected for the purposes to match the research objectives. The community forest is situated in ward no 8 and 9 of Tulsipur Municipality, Dang district. The total area of CF is 207.05 ha, the total number of household were 1310 (Figure 1).

\section{Sampling method}

Systematic random sampling method was used for collecting forest inventory data. Altogether 49 (1.5\% sampling intensity) sample plots were taken. GIS tool called fishnet was applied to allocate sample points and survey was done using handheld GPS (Garmin 64s). The sampling was carried out in the plot of $25 * 20$ for trees, $10 \mathrm{~m}^{*} 10 \mathrm{~m}$ for poles, $5 \mathrm{~m} * 5 \mathrm{~m}$ for saplings and $5 \mathrm{~m} * 2 \mathrm{~m}$ for seedlings.

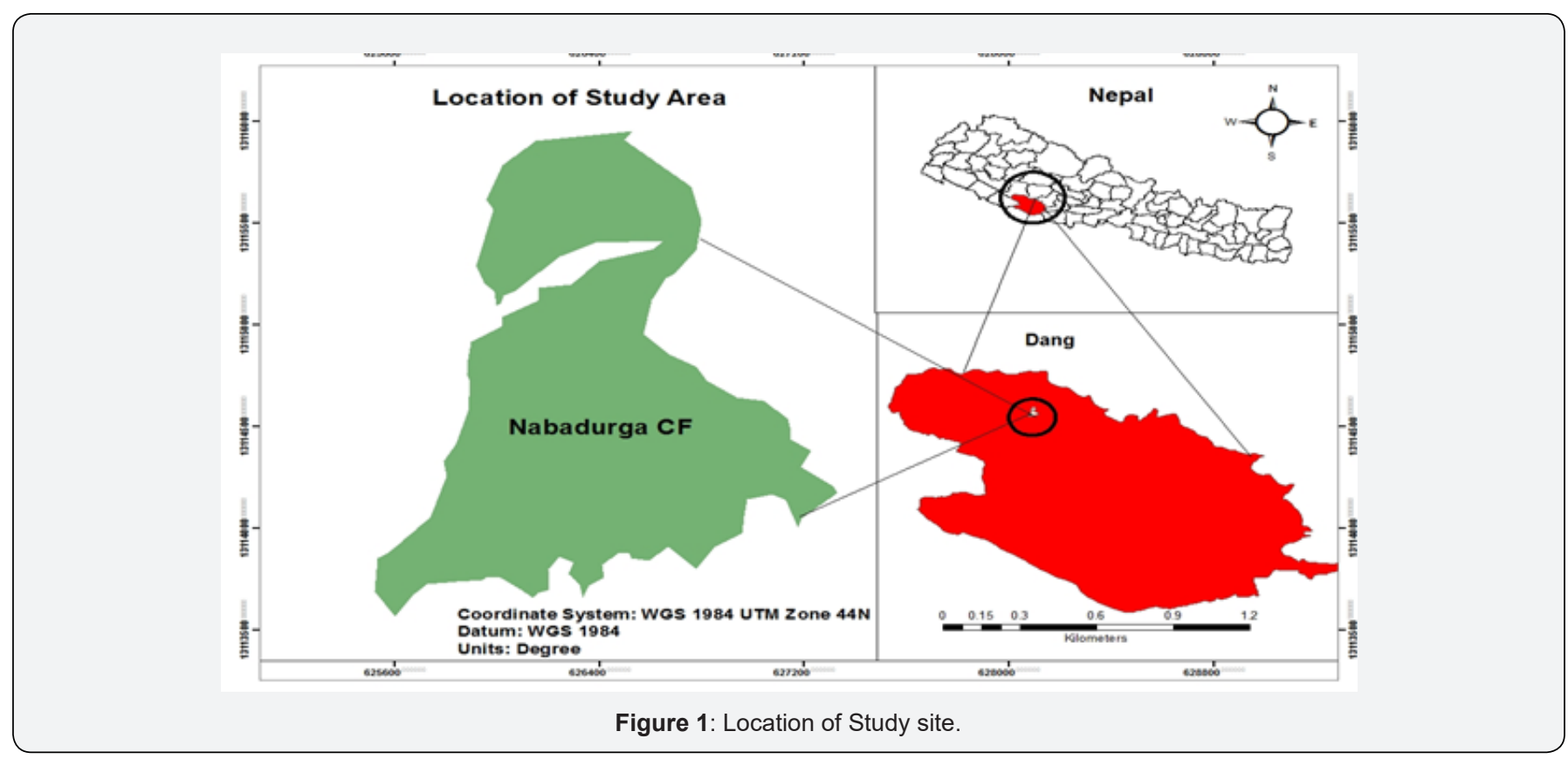

Similarly, for the social information, PRA tools such as Households survey (HHs), Key informants survey, focus group discussion were carried out. Out of 1310 households, 69 households were selected following the formula by Arkin \& Colton [16].

$$
n=\frac{N z^{2} P(1-P)}{N d^{2}+z^{2} P(1-P)}
$$

Where,

$\mathrm{n}=$ Sample size.

$\mathrm{N}=$ Total number of HHs.

$\mathrm{z}=$ Confidence level (at 95\% level $\mathrm{z}=1.96$ ).

$\mathrm{P}=$ Estimated population proportion $(0.05$, this maximize the sample size).

$d=$ error limit of $5 \%(0.05)$.

\section{Data analysis}

Microsoft excel was used for data analysis. Forest condition of the community forest was analyzed according to the quality/ condition of regeneration and sapling and the stem volume per hectare. The criteria used for the analysis of forest condition was adopted from the forest resources inventory guideline 2005 developed by the Department of Forest (DoF). The perception of users regarding the management system was analyzed using likert scale method. The responses of the respondent were measured in 5 different levels namely "strongly agree", "agree", "Moderately agree" (or okay), "disagree" and "strongly disagree" in a Likert format. Number weight was assigned to each response option from 5 to 1 in an order of 'strongly agree' to 'strongly disagree'. From the number weight and frequency of each option, Likert score was calculated as follows:

Likert Score $=$ Total number weight/ $(5 *$ Number of respondents) $* 100 \%$ 
The interpretation of Likert scores was done as presented in following Table 1

Table 1: Interpretation of Likert Scale.

\begin{tabular}{|c|c|c|}
\hline Score Range & Scale & Description or Conclusion \\
\hline $85-100 \%$ & $\begin{array}{c}\text { Strong or Very } \\
\text { good }\end{array}$ & $\begin{array}{c}\text { Highly satisfactory and need to } \\
\text { continue as it is }\end{array}$ \\
\hline $65-84 \%$ & Strong or good & $\begin{array}{c}\text { Satisfactory but there is still room } \\
\text { for improvement }\end{array}$ \\
\hline $50-64 \%$ & Medium & $\begin{array}{c}\text { Not dissatisfactory but there re- } \\
\text { main many things to improve }\end{array}$ \\
\hline $35-49 \%$ & Weak or disagree & $\begin{array}{c}\text { Unsatisfactory and needs excessive } \\
\text { improvement }\end{array}$ \\
\hline$<35 \%$ & $\begin{array}{c}\text { Very weak or } \\
\text { strongly disagree }\end{array}$ & $\begin{array}{c}\text { Very unsatisfactory and significant } \\
\text { change is urgent for improvement }\end{array}$ \\
\hline
\end{tabular}

\section{Results and Discussion}

\section{Forest Condition}

The forest is pure Sal forest in every size class (ie Seedling, Sapling, Pole and tree). Sal accounts for $94 \%$ of total stems in all classes. Syzygium cumini (Jamun) exists as an associate species accounting $4 \%$ of total stems respectively. The average number of seedling per ha was 8701 and sapling was 1950. According to forest resource inventory guideline [17], seedling condition is good if number of seedling is $>5000$ per ha, sampling condition is good if $>2000$ per ha. Similarly, seedling and sapling condition is fair if number of seedling is 2000-5000 per ha and 8002000 per ha. Thus, while comparing the data with inventory guidelines, condition of regeneration and sapling in the forest is satisfactory. Similarly, comparing the data with Community Forest Operation Plan (CFOP) 2014 of the CF, there were 5615 seedling per ha and 2766 sapling per ha. These two figures could not be compared directly as the size and location of plot was not similar. However, the number of seedlings in the present study was found to be increasing order but in case of sapling, it was in decreasing order. Thus, it may be assumed that during the period sapling might turn into poles. Similarly, in this CF, the average tree and pole stand per ha were 38 and 1033 respectively. Further, comparing the data with CFOP of 2014 there were 25 trees per ha and 1641 poles per ha. These two results may not be comparable as the numbers and location of plots were different. However, in the present study the numbers of trees were found to be in increasing order but in the case of poles, it was in decreasing order. Thus, it may be assumed that during the period, some poles were harvested during thinning operations and some poles might have turned in to trees during the period. On the other hand, the average growing stock was $225.6 \mathrm{~m} 3 / \mathrm{ha}$. Following the criteria by forest resource inventory guideline [17], any forest with growing stock $200 \mathrm{~m} 3 /$ ha is regarded as good forest. Since Nabadurga CF'S exceeds the criteria given by DOF, it can be regarded as good forest.

\section{Existing forest management system}

In this $\mathrm{CF}$, under five years management plan selective felling has been applied. The whole forest has been divided into five different blocks. The yearly product supply from this system is significantly low. There is gap between demand and supply of forest products.

\section{Demand and supply situation}

Table 2: Demand and Supply Situation in the CF.

\begin{tabular}{|c|c|c|c|}
\hline Forest Products & Demand & Supply by CF & Deficient \\
\hline Timber (Cubic feet) & 3460 & 1150 & 3345 \\
\hline Fuel wood (Bhari) & 9226 & 7430 & 1796 \\
\hline Fodder (Bhari) & 5350 & 3120 & 2230 \\
\hline
\end{tabular}

Source: Operation Plan of community forest (2014-2018).

(Table 2) While looking at the demand and supply situation of timber, fuel wood and fodder, CF has been unable to fulfill the required demand of user groups from the forest. Only, about $33 \%$ of the timber and $80 \%$ of fuel wood and $50 \%$ of fodder demand has been fulfilled by the CF as mentioned in CFOP (2014-2018). There is still chance of increase in demand in the upcoming year with the increase in household number. Maximum productivity of forests is very essential to meet the increasing demand of forest products. The implication of active forest management system could increase forest product supplies [18].

\section{Income and expense scenario in past two years}

Since the long-term data was not available, expenditure and income of the CFUG were evaluated on the basis of two years data (Table $3 \& 4$ ).

Table 3: Income of CF in Past two years.

\begin{tabular}{|c|c|c|c|}
\hline S. No & Income Sources & 2017 (US\$) & 2016 (US\$) \\
\hline 1 & \multicolumn{3}{|c|}{ Forest Products } \\
\hline & Timber and fuel wood & 3699.1 & 3962.8 \\
\hline & Fodder and grass selling & & 125.6 \\
\hline \multirow[t]{5}{*}{2} & \multicolumn{3}{|c|}{ Households } \\
\hline & New membership & 300 & 4650 \\
\hline & Application Form & 18.5 & 10.1 \\
\hline & Membership renewal & 539.5 & 1280.54 \\
\hline & Penalties/Fine & 2 & 4 \\
\hline \multirow[t]{3}{*}{3} & \multicolumn{3}{|c|}{ Donations } \\
\hline & DFO & & 1500 \\
\hline & Organizations & 1000 & 350 \\
\hline \multirow[t]{3}{*}{4} & \multicolumn{3}{|c|}{ Others } \\
\hline & Rotating fund & 210 & 150 \\
\hline & Total & 5769.1 & 12033.04 \\
\hline
\end{tabular}

(Note: 1 US $\$=100$ Nepali Rupees). 
The total income of Nabadurga CFUG in past two years was 17802.14 US\$ out of which income from forest products only was 7787.5 US\$ i.e. $43.7 \%$. The total expenditure of Nabadurga CFUG in past two years was found to be 14961.8 US\$ out of which the expense was highest for the forest management i.e. 5020 US\$(33.5\%). The benefit cost ratio in past two years was found to be $0.189<1$. Similarly, the net present value calculated was found to be 21774.68 US\$. While seeing the overall Scenario $\mathrm{CF}$ activities are mainly depended upon financial source from activities (Donations, membership renewal etc) other than the sale of forest products.

Table 4: Expense of CF in past two years.

\begin{tabular}{|c|c|c|c|}
\hline S. No & Area of Expenditure & 2017 (US\$) & 2016 (US\$) \\
\hline 1 & Forest management & 1821 & 3199 \\
\hline 2 & Silvicultural Operation & 202 & 677.45 \\
\hline 3 & Construction Cost & 1220 & 2762 \\
\hline 4 & Social development & 90 & 731.5 \\
\hline 5 & Watch guard & 766 & 875 \\
\hline 6 & Auditing Cost & 70 & 60 \\
\hline 7 & Transport & 141.22 & 272 \\
\hline 8 & Various Support & 11 & 580.35 \\
\hline 9 & Food and communication & 279.83 & 350 \\
\hline 10 & Rotating Fund & 210 & 237 \\
\hline 11 & Others & 406.45 & 9744.3 \\
\hline 12 & Total & 5217.5 & \\
\hline
\end{tabular}

\section{Perception of users regarding existing forest management system}

Table 5: Perception of users regarding existing forest management system.

\begin{tabular}{|c|c|c|c|c|c|c|c|c|}
\hline S.No & Statements & Very High & High & Low & Very low & None & Likert Score (\%) & Interpretation \\
\hline 1 & $\begin{array}{l}\text { Forest products extracted from } \mathrm{CF} \text { has } \\
\text { reached to distant users }\end{array}$ & 7 & 10 & 36 & 16 & & 43 & Weak or disagree \\
\hline 2 & $\begin{array}{l}\text { Illegal extraction and felling have been fully } \\
\text { controlled }\end{array}$ & 14 & 31 & 17 & 4 & 3 & 74 & Strong or good \\
\hline 3 & Forest Condition and health is improving & 5 & 40 & 17 & 5 & 2 & 72 & Strong or good \\
\hline 4 & $\begin{array}{l}\text { Income generating activities of CFUG mem- } \\
\text { bers has increased through CF activities }\end{array}$ & & 2 & 9 & 40 & 18 & 39 & weak or Disagree \\
\hline 5 & Biodiversity Conservation/Ecosystem & 16 & 34 & 17 & 2 & & 79 & Strong or good \\
\hline 6 & $\begin{array}{l}\text { Job creation in local level and supportive } \\
\text { for livelihood }\end{array}$ & & 3 & 16 & 21 & 29 & 38 & Weak or disagree \\
\hline 7 & Maintenance of greenery & 22 & 38 & 7 & 2 & & 84 & Strong or good \\
\hline 8 & Regular in silvicultural operation & & 3 & 14 & 33 & 19 & 41 & Weak or disagree \\
\hline 9 & $\begin{array}{l}\text { Sufficient quantity of forest products to the } \\
\text { user groups }\end{array}$ & & & & 31 & 38 & 29 & $\begin{array}{l}\text { Very weak or } \\
\text { strongly disagree }\end{array}$ \\
\hline
\end{tabular}

The respondents were asked for their intensity of agreement to different statements related to existing management system. The Likert scale was divided into 5 scale with score 1 to 5 ; where 1 score indicate disagree or none, 2 indicate very low, 3 indicate low or fair, 4 indicate high and 5 indicate very high position of agreement regarding the asked statement and then calculated the Likert score (\%). From the number weight and frequency of each option, Likert score was calculated, and interpretation was done as illustrated in data analysis section of methodology chapter. Survey result and perception of 69 respondents regarding the forest management is presented in Table 5. The overall response of respondents was 55\% which indicated that the existing forest management in Nabadurga was somehow satisfactory in terms of conservation of the forest but on the other hand results shows that users are in need of productive forest rather than protective. Thus, maintenance of balance between protection and utilization of the forest products is one of the prime concerns in Nabadurga CF. In conclusion, management system of CF needs to be improved to increase production and productivity of the forest. 


\section{Suggestion regarding forest management system by forest users}

The effects of forest management depend on how well it is performed, which in turn depends on the level of development and effectiveness of Forest User Group institution. Table 6 shows different indicators and users' suggestion towards effective forest management. The active forest management approach calls for the various silvicultural and harvesting activities in the forest $[19,20]$. It has been often reported that most of the failure cases in resource management are because of mismatch between the real condition of resource and adopted management plan [21]. From the beginning of community forest establishment, the issue regarding demand and supply of forest products was highly voiced. Second generation issues of community forest also focused on sustainable forest management. However, till now a pattern of removal of only certain species of higher value of trees above certain size, commonly called as selective felling is seen. Promoting active management approach to carry out research on silvicultural system for different forest types and management regimes had been urgent due to consequence of traditional forest management like deteriorating forest condition, increasing gap of forest products demand and supply and failure to regenerate revenue as per the productive capacity of the forest [22]. There is a growing demand for information from local community as well as forestry professional on how forest could be managed to meet the demand of forest products that essential to sustain rural livelihood [8]. Low impact of CF to rural livelihoods is brought about by the lack of active forest management to enhance productivity [23]. Efforts are needed to design silvicultural regime for Sal forest to produce a range of products including timber [24]. Subedi [22] suggested reorienting policies, priorities and human resources towards immediate initiation of SFM; carrying out research on silvicultural systems for different forest types and management regimes; and promoting adaptive management approach. Similarly, Government of Nepal (GON) has promulgated a scientific forest management (SFM) working plan in October 2014 for effective Terai Sal forest management. Government expected to generate about 300 million USD annually after the implementation of this plan, many times higher than the current contribution of the forestry sector to the national economy [25]. Khadka [18] also suggested that scientific intervention is needed in forests and following strictly the silvicultural system is the most in all types of forests. Again, community perception on Nabadurga Community forest management is also somehow unsatisfied for demand fulfillment and forest management. So, for demand fulfillment, ecological viability and social satisfaction, management system of $\mathrm{CF}$ needs to be improved to increase production and productivity of the forest. Current management regime tends to lean towards conservation and protection of the forest resources. But future management regime should integrate conservation and production so as to increase production, income and employment of the people to uplift the living standard of people for overall benefit, which could be possible through SFM.

Table 6: Suggestion regarding forest management system by forest users.

\begin{tabular}{|c|c|}
\hline Indicators & Suggestion \\
\hline \multirow{2}{*}{ Improved forest Condition } & All open land should be covered with plants and grasses. \\
\hline & Forest with different age-group stands including large mature trees, to keep fulfilling users' needs. \\
\hline \multirow{4}{*}{ Products Distribution } & Forest products should easily available \\
\hline & Equitable sharing in forest products. \\
\hline & Continuous supply of different products to fulfill the different needs of forest \\
\hline & user' \\
\hline \multirow{3}{*}{ Active forest management } & Regular in silvicultural operations. \\
\hline & SFM should be introduced. \\
\hline & Rotational block wise management system should be established. \\
\hline \multirow{2}{*}{ Sustainable/Secure Product } & Secure current and availability of forest products \\
\hline & Forest should carefully utilize without waste \\
\hline
\end{tabular}

\section{Conclusion}

Nabadurga Community forest is Pure Sal forest with good condition having growing stock $225 \mathrm{~m} 3 /$ ha and number of seedling and sapling per hectare 870 and 350 respectively. The total income of Nabadurga CFUG in past two years was 17802.14 US\$ out of which income from forest products was 7787.5 US\$ i.e. $43.7 \%$. The total expenditure of Nabadurga CFUG in past two years was found to be 14961.8 US\$ out of which the expense was highest for the forest management i.e. 5020 US\$(33.5\%). However, current management practices tend to lean towards conservation of the forest only. The people's perception also showed that the existing management system is good for the purpose of protection and conservation of the forest, but it doesn't fulfill the need of the users. As forests are natural resources the utilization of forest production in an efficient and sustainable manner should not be hindered by only protectionoriented approaches. Thus, to meet the forest demand, keeping 
the forest sustainably sound, shift in existing management practices is necessary.

\section{Acknowledgement}

We would like to acknowledge Kathmandu Forestry College team for their tremendous support during this research. We are also thankful to Mr. Krishna Ram Dhital who paid a huge contribution in conducting this research and in report preparation. Similarly, we would like to thank Mr. Pratik Pandey for his kind support and suggestions during the data collection.

\section{References}

1. Acharya KP (2003) Sustainability of Support for Community Forestry in Nepal Forests, Trees and Livelihoods 13(3): 247-260.

2. Yadav NP, Dev OP, Springate-Baginski O, Soussan J (2003) Forest management and utilization under community forestry. Journal of Forest and Livelihood 3(1): 37-50.

3. Gilmour DA, Fisher RJ (1991) Villagers, Forests and Foresters: The Philosophy, Process and Practice of community forestry in Nepal, Sahayogi Press, Kathmandu, p. 212.

4. Shrestha BP (2000) Lobbying and advocacy as a means for realising rights over common property resources. Paper presented at "Constituting the Commons: Crafting Sustainable Commons in the New Millennium", the Eighth Conference of the International Association for the Study of Common Property, Bloomington, Indiana, USA, May 31June 4.

5. Sigdel H, Shah R, Khanel K (2005) Terai Forest Management: Why and How? Hamro Ban Sampada 3(2).

6. Baral JC (2002) Depleting Forest, Silent Spectors: Who should Manage Nepal's Terai Forest? Journal of Forest and Livelihood 2(1): 34-40.

7. Pesonen P (1994) The Potential of the Natural Forests of the Terai and the New Principles of Forest Management. FMUDP Working Paper 15, Kathmandu: Forest Management and Utilization Development Project, HMGN/FINNIDA.

8. Acharya KP (2002) Twenty-Four Years of Community Forestry in Nepal International Forestry Review 4(2): 149-156.

9. Go N (1989) Master Plan for the Forestry Sector Nepal Ministry of Forests and Soil Conservation, Kathmandu, Nepal.

10. Joshi SP, Rautiainen O, Suoheimo J (1995) Silvicultural guidelines for the implementation of operational forest management plans in the Terai, Nepal. FMUDP Technical Report No. 15. HMGN/FINNIDA, Kathmandu. Nepal.

11. DFRS (2015) State of Nepal's Forests. Forest Resource Assessment (FRA) Nepal, Department of Forest Research and Survey (DFRS). Kathmandu Nepal.
12. Awasthi N, Bhandari SK, Khanal Y (2015) Does scientific forest management promote plant species diversity and regeneration in Sal (Shorea robusta) forest? A case study from Lumbini collaborative forest, Rupandehi, Nepal. Banko Janakari 25(1): 20-29.

13. Gautam KH (1990) Regeneration Status of Sal (Shorea robusta) Forests in Nepal. Department of Forest Nepal, Kathmandu, p. 11.

14. Shrestha BP (1992) Evaluation of Sal (S. robusta), Sissoo (Dalbergia sissoo) Management in Nepal through Publications and Field Experience. Forest Management and Utilization Development Project. Technical Report No. 2, FMUPP, Kathmandu, Nepal.

15. Acharaya KP (2000) Unfavorable Structure of Forest in the Terai of Nepal needs immediate management, Banko Jankari 10(2): 25-28.

16. Arkin H, Colton RR (1963) Tables for statisticians. (2nd edn), New York: Barnes and Noble Books, contributed by National Library of Australia 5(4): 187-196.

17. GoN (2005) Community Forestry Resource Inventory Guidelines. Department of Forest, Community Forestry Development Division Kathmandu

18. Khadka, Ananda (2016) Silviculture in a changing world Scientific Intervention in Collaborative Forest (Change in Management paradigm).

19. Acharya KP (1997) The Management of Common Forest Resources: An Evaluation of Bharkhore Forest User Group, Western Nepal. M.Sc. Thesis, the University of Edinburgh, Scotland, UK.

20. Branney P (1996) The New Silviculture: India and Nepal. In: Hobley M (ed), Participatory Forestry: The Process of Change in India and Nepal ODI, London, pp. 190-210.

21. Hobley, Mary (1996) Participatory Forestry and the Process of Change in India and Nepal. Rural Development Forestry Study Guide 3, Rural Development Forestry Network, Overseas Development Institute, London. UK.

22. Subedi VR (2012) Forest Management Opportunities and Challenges in Nepal (in Nepali). Hamro Ban Sampada 10(1): 61-68.

23. Yadav N, Yadav K, Yadav K, Thapa N (2009) Facilitating the transition from passive to active Facilitating Transition from Passive to Active Management of Community Forests in Nepal: Lessons from Livelihoods and Forestry Programme. Forest Action Discussion Paper 8: 2.

24. Gautam KH, Devoe NN (2005) Ecological and anthropogenic niches of sal (Shorea robusta Gaertn. f.) forest and prospects for multiple-product forest management - a review. Forestry: An International Journal of Forest Research 79(1): 81-101.

25. Rai R (2015) The forest of Hume pipe: Ripe for the picking. March 6, 2015. South Asia Network for Development and Environmental Economics (www.sandeeonline.org). 
Your next submission with Juniper Publishers will reach you the below assets

- Quality Editorial service

- Swift Peer Review

- Reprints availability

- E-prints Service

- Manuscript Podcast for convenient understanding

- Global attainment for your research

- Manuscript accessibility in different formats ( Pdf, E-pub, Full Text, Audio)

- Unceasing customer service

Track the below URL for one-step submission https://juniperpublishers.com/online-submission.php 